\title{
INFLUENCE OF SECURITY AND TRUST ON ELECTRONIC BANKING ADOPTION IN SLOVAKIA
}

\author{
Martin Vejačka, Tomáš Štofa
}

\section{Introduction}

The rapid development of information and communication technologies (ICT) in recent years has brought major changes in many areas of the economy and even created its new sectors. Rising complexity of technological and heterogeneity of technological infrastructure and their applications contributed to changes in every business area (Voříšek et al., 2015). New opportunities to sell products and provide services arose in the electronic environment. Customers routinely buy in e-shops and electronic banking became a very important form of banking services usage in last two decades. Improvements in information and communication technologies have positively influenced also areas like retail commerce, banking, public administration, healthcare administration (Šoltés \& Gavurová, 2014) and many others. Significant changes occurred in the provision of banking services. Some of the forms of electronic banking quickly became old and out-dated (e.g. Wireless Application Protocol - WAP banking). Faster data transmissions within mobile networks and the Internet allowed multiple innovations and improvements of electronic banking forms. The form of electronic banking growing fast in numbers of users is mobile banking in smartphones and tablets (and other devices). This form of mobile banking uses dedicated application installed in mobile device allowing active usage of banking services, although for communication with the bank it uses mostly the Internet (mobile network, Wi-Fi etc.).

Claessens et al. (2002) adduced that electronic provision of banking services brings many benefits to its users and also to providers, e.g. cost savings for both sides of banking services, higher speed of service, almost unlimited availability and higher conformability. When clients want to benefit from electronic banking, they must trust in electronic banking.
In general, trust in information and communication technology affects the adoption of ICT. Additionally, information and communication technologies may promote trust while they allow faster and more reliable acquisition of information and support transparency. Delina and Dráb (2010) stated that trust within the electronic environment is often connected with reputation mechanisms, which allows reputation assigning to the both sides of the commercial relationship to assess their trustworthiness. In the case of e-commerce trustworthy seller (the one that sends his goods on time and in demanded quality and quantity) should have high reputation generated by previous sales.

Multiple publicized cases of major security failures have increased public concerns about electronic commerce and reduced their trust in it. This is especially true for the area of electronic banking as one of the areas of e-commerce while customers are more concerned about security when the process includes sensitive personal information. In electronic banking, sensitive personal financial information is manipulated and its customers are concerned about the security issues of e-banking form what may inhibit their use of electronic banking.

In the case of electronic banking, the provider of electronic banking service is banking institution, which is liable to various banking committees and supervising authorities. So clients of electronic banking services have a high level of certainty that the other side of this commercial relationship (the bank) is a serious and trustworthy partner under the supervision of higher authority. On the other hand, electronic banking uses various electronic environments where abuse might be unseen until the very last moment. Attacks by third parties on electronic banking of its users (e.g. phishing, pharming etc.) might be a source of risk that dissuades 
potential users from e-banking usage. Therefore banks are trying to prevent such a threat by increasing level of electronic banking security and safety of its use.

Lev-On (2009) explored the importance of trust in an online environment and pointed out the difference between security and trust. Hawkins and Sato (2004) investigated the trust in electronic finance and banking with finding that both non-technical and technical aspects of trust building must be covered to provide confidence and trust for users in this area by financial and banking institutions. Trust in electronic banking providers is generated mainly by bank supervision and dispensing of banking license by higher authorities.

Competition among banks in retail area pushes them to improve also comfort and security of their electronic banking services, although occasional cases of e-banking abuses noted in media might disrupt the confidence of electronic banking users as stated Dandapani (2004). Furthermore establishing, adopting and strict application of security procedures and policy in electronic banking is an issue according to Simpson (2002).

Potential bank clients might sense both multiple advantages and risks of electronic banking when deciding whether to adopt it or not. Faster service, great availability and higher comfort of use are benefits attracting potential users to the electronic banking. On the other hand, doubts about safety and security of electronic banking might impede its adoption by potential clients. Further banks are seeking costs reduction, higher efficiency, customer satisfaction and possibility to serve to more customers at once when introducing electronic banking (Mittal \& Kumra, 2004; Berger et al., 2007).

Electronic banking acceptance in Slovakia was investigated in Vejačka (2014), however, trust in electronic banking was not considered specifically. Investigation of the influence of trust and security on electronic banking adoption in the conditions of retail banking in Slovakia will be the main goal of this paper. The extent of the influence of further identified factors on electronic banking adoption by its potential users in Slovakia will be investigated.

\section{Literature Review}

Many research studies investigate customer acceptance of internet banking or electronic banking in general (including other forms of e-banking besides internet banking). The most of these studies are based on the Technology Acceptance Model established by Davis (1989). Technology Acceptance Model (TAM) detects factors of perceived usefulness, perceived ease of use, and awareness of particular technology investigated. In studies dedicated to electronic banking, the TAM is often further extended or adapted by some specific aspects of electronic banking technology to investigate their influence on electronic banking acceptance (e.g. Venkatesh \& Davis, 2000). TAM serves for development of the research model, which is further verified by factor analysis, which can test how well the measured variables represent the number of factors, firstly developed by Jöreskog (1969).

Pikkarainen et al. (2004) detected web information about electronic banking service as one of the main factors predicting acceptance of given service. Teo et al. (1999) included in their version of TAM also perceived enjoyment. It was detected as a significant inherent motivator to information system usage.

Cheng et al. (2006) investigated the acceptance of internet banking in Hong Kong using Technology Acceptance Model. Their research results indicated the suitability of using TAM for investigating customer's acceptance of internet banking. Qureshi et al. (2008) also confirmed TAM as suitable for online banking acceptance prediction using data from developing countries.

Agarwal and Karahanna (2000) extended TAM with perceived playfulness and ascertained that perceived playfulness is prior to the perceived ease of use and perceived usefulness. Furthermore, Moon and Kim (2001) detected its significant influence of customer technology adoption in the world-wide-web context. Werber et al. (2015) indicated that computer literacy is a key factor in adopting new information and communication technology.

Multiple authors aimed their research to the effects of trust on acceptance of various technologies, like e-commerce and electronic banking. Jarvenpaa et al. (2000) investigated purchase behavior at online stores. According to their findings trust influences perception of risk and attitude toward purchase at given online store and trust itself was influenced by the perceived reputation and size of the store.

Gefen (2002) examined the influence of trust on purchase intentions in an online 
environment and detected the significant influence of trust, which is further affected by benevolence and integrity. Influences on the intent to make Internet purchases were also investigated by George (2002), who detected privacy and the Internet trustworthiness as main significant factors affecting the decision about purchases on the Internet. Gefen et al. (2003) later investigated purchase intentions of experienced and inexperienced customers in online stores and ascertained the significant effect of disposition to trust and familiarity on trust, which significantly influences customers' intentions to purchase.

Bhattacherjee (2002) examined if the consumers are complaisant to make online transactions. His results suggested that compliance to transact online is affected by familiarity and trust. Trust has a significant effect on willingness to transact according to Pavlou (2003) and is a determinant of perceived usefulness in an online environment.

In general, the low trust in an electronic environment is often considered as an important barrier to wider proliferation of electronic banking (Yousafzai et al., 2009). The results of Aladwani (2001) and Lee and Turban (2001) showed that privacy and security concerns hinder the adoption of Internet banking and lower trust. Suh and Han (2002) detected trust's significant influence on attitude towards using Internet banking and its overall acceptance by potential users. Sohail and Shanmugham (2003) found out that trust in customer's bank has a significant effect also on Internet banking adoption by given customer among other factors like security concerns, attitude towards change and availability of the Internet.

Many researchers examined also the influence of security on trust in electronic banking and consequently on its adoption by potential users. Pikkarainen et al. (2004) did not detect the influence of security on electronic banking acceptance. The research of Widjana and Rachmat (2011) also showed similar results. On the other hand, many studies detected importance of security and safety when introducing electronic banking to their potential users. Roboff and Charles (1998) detected importance of privacy of financial information in cyberspace and suggested banks to address consumers' concerns in this area. Chellappa and Pavlou (2002) adduced that security concerns very often accompany an introduction of new information technologies. Then, the acceptance of these novel technologies depends on preventing of security threats, improving the perception of security by consumers and building their trust in given technology. Hamlet and Strube (2000) indicated that safety of online banking perceived by bank clients will affect its adoption. Dzemydienè et al. (2010) explored security disturbance risks in electronic banking systems. According to their results, multiple risk factors and the implementation of modern ICT technologies increase the security of electronic payment security and significant efforts must be made to build the trust by prevention of security risks.

Alsajjan and Dennis (2006) investigated the influence of trust on sensitive information use in online banking and on user's acceptance of electronic payments. The results of GrabnerKräuter and Faullant (2008) showed a significant influence of privacy on customer attitudes towards internet banking on risk perception while using it. Qureshi et al. (2008) ascertained that high perceived security of online banking together with perceived usefulness led to a significant shift from traditional banking to electronic banking. Good security and privacy levels according to findings of Geetha and Malarvizhi (2011) increased the adoption of electronic banking services by banking customers in India. Acceptance of electronic banking by customers, in this case, was also affected by safety guidance from bank's side.

Alsajjan and Dennis (2010) examined the managerial side of consumer acceptance of internet banking. Internet banking customer must perceive electronic transactions as safe and easy to promote internet banking adoption. It builds a trust in internet banking in a significant way according to their findings. Furthermore, banks should create their reputation as innovative institutions and promote positive perception and trustworthiness in eyes of potential customers. For these promotional purposes, banks should use digital media like blogs, social networks and emails.

Kumar et al. (2012) highlighted the importance of the reducing the risk of the internet banking customer by bank's structures, including security, assurances, service quality and benevolent policies. They also detected the effects of the individual's customers' attitude towards the internet and internet banking on the disposition to trust. The banks 
should communicate to users all its benevolent policies to enhance the level of the internet banking usage in order to positively influence their disposition to trust with the aim to increase the level of the internet banking usage.

Researchers often explore the acceptance of online banking, aiming their research only on internet banking. However, customers might use more forms of electronic banking at present. Mobile banking using internet connection (in the case of Slovakia called Smart banking) or mobile network is a most common alternative to internet banking. In many countries around the world, investigations on electronic banking adoption by customers were realized during recent years, e.g. in Australia (Sathye, 1999), Turkey (Polatoglu \& Ekin, 2001), United Kingdom (Howcroft et al., 2002), Finland (Karjaluoto et al., 2002), Hong Kong (Cheng et al., 2006), Pakistan (Qureshi, 2008), India (Geetha \& Malarvizhi, 2011), Romania (Moga et al., 2012), Nigeria (Popoola, 2013) or in Vietnam (Nguyen et al., 2014).

A similar investigation of electronic banking adoption in Slovakia was conducted (Vejačka, 2014). However, this research was not aimed at security and trust influence on electronic banking acceptance. Therefore the issue of trust and security influencing electronic banking adoption by potential users in Slovakia will be the focus of this study.

\section{Research Model}

Multiple models of trust within the environment of electronic banking or services were used during investigations. McKnight et al. (2002) suggested the trust model on the web. In this model, the adoption of the e-commerce system depends on the customers' trust in the web, which is related to trusting beliefs and disposition to the trust of the customer. Kumar et al. (2012) adopted this model for use in case of internet banking (that can be considered as an extension of e-commerce) to reflect various technology-related trust dimensions influencing the institution-based trust.

According to Tan and Thoen (2001), trust is determined by four basic beliefs: competence belief, dependence belief, disposition belief and fulfillment belief, while competence belief reflects the usefulness of supplier of product or service perceived by the customer. The same assumption can be applied to electronic banking or basically to any information technology. Perceived usefulness is one of acceptance factors according to TAM developed by Davis et al. (1989). Suh and Han (2002) extended TAM with the concept of trust influencing attitude toward using and behavioral intention to use, while trust itself is influenced by perceived usefulness and in turn by perceived ease of use.

In this research, foundations of technology acceptance model are used with modifications similar to those made in the study of Suh and Han (2002). However, factors of perceived usefulness and perceived ease of use are not considered because their influence is well investigated in many studies using TAM. In our study perceived security is examined instead, while it is one of the basic aims of our research. Influence of both, perceived usefulness and perceived ease of use on electronic banking acceptance, was already investigated in Slovak conditions (Vejačka, 2014). However, in this research, the influence of security and trust on electronic banking acceptance will

\section{Fig. 1: Research model}

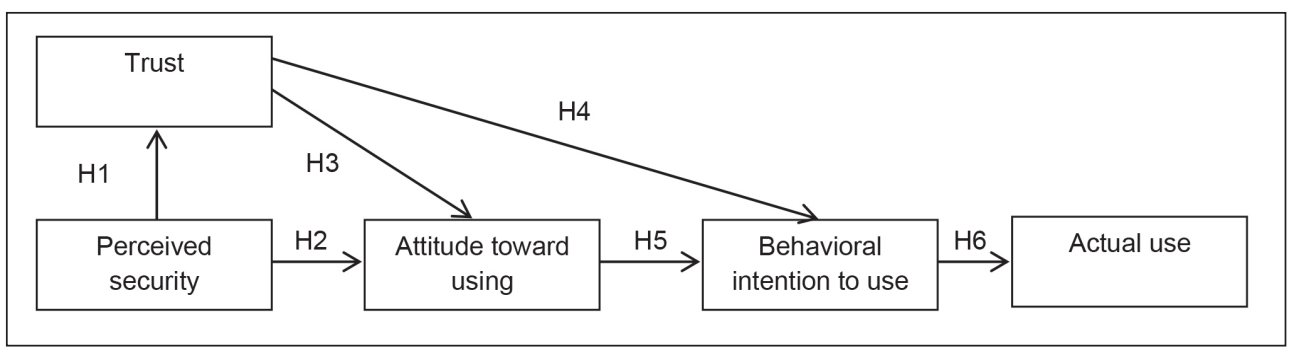

Source: own 
be investigated together with the effect of perceived security on trust in electronic banking. The constructed research model is graphically presented in Fig. 1.

According to model following research hypotheses are formulated:

H1: Perceived security has a positive impact on customer's trust in electronic banking.

Kumar et al. (2012) found that security of internet banking perceived by users has significant positive influence on institutionbased trust in internet banking. It can be generalized also for other forms of electronic banking. Sanayei and Noroozi (2009) stated that trust is increased and positively associated with the perceived level of security.

H2: Perceived security has a positive impact on customer's attitude toward using electronic banking.

The security mechanisms support customers' confidence to interact with electronic banking according to Suh and Han (2002). Liao and Cheung (2002) suggested that the visibility of these security mechanisms to the users is important and influences customer's attitude toward using internet banking or electronic banking in general.

H3: Customer's trust has a positive impact on customer's attitude toward using electronic banking.

Customer's trust in store positively influences attitude toward using given store according to Macintosh and Lockshin (1997) and attitude is one of the components of store loyalty. Also, Jarvenpaa et al. (2000) suggested that customer trust in an online store strongly influences attitude toward using particular online store.

H4: Customer's trust has a positive impact on customer's intention to use electronic banking.

Influence of trust on behavioral intention to use any service was investigated mainly in the marketing area. Gefen et al. (2003) suggested that trust positively influences buyer's intention to use the online store of the seller.
This hypothesis was adopted for the case of electronic banking usage.

H5: Customer's attitude toward using electronic banking has a positive impact on customer's intention to use electronic banking.

Suh and Han (2002) verified in their study that customer's attitude toward using internet banking has a positive impact on his/her actual use of it. This hypothesis has been modified to the form for all electronic banking forms and is part of our research model.

H6: Customer's intention to use electronic banking has a positive impact on customer's actual use of electronic banking.

Again, Suh and Han (2002) investigated and confirmed positive impact of customer's intention to use internet banking on actual use of it. Also, this hypothesis is incorporated in form of influence of electronic banking in our research model.

\section{Methodology}

Our research model mentioned in previous chapter was developed on the basis of the Technology Acceptance Modelling (TAM) approach with factors of perceived security, trust, attitude towards using and behavioral intention to use electronic banking. With an aim to verify our research model, data was gathered using an online survey. The questionnaire survey was aimed to investigate factors influencing electronic banking adoption showed in our research model.

Potential factors of were further investigated by confirmatory factor analysis, which is contemporary technique for assessing the construct validity of multiple attempts to measure the same concept being in agreement. Confirmatory factor analysis is a multivariate statistical procedure that is used to test how well the measured variables represent the number of constructs (factors). It is a tool that is used to confirm or reject the measurement theory. It was developed by Jöreskog (1969). Confirmatory factor analysis serves to detect factors accounting for the covariance in the measures, while these factors are being unrelated to each another. The theoretical measurement model is compared with the reality model to detect how well the data fits. Chi-square test 
and other goodness of fit statistics like root mean square residual, goodness-of-fit index, normed fit index, comparative fit index are key indicators that might indicate measuring the model validity, i.e. how well the proposed model captured the covariance between all the items or measures in the model (Hair \& Black, 2010). If the constraints the researcher has imposed on the model are inconsistent with the sample data, then the results of statistical tests of model fit will indicate a poor fit, and the model will be rejected. If the fit is poor, it may suggest that some items measuring multiple factors, or some items within a factor are more related to each other than others. Confirmatory factor analysis is often used in technology acceptance studies, like Suh and Han (2002), Cheng et al. (2006), Kumar et al. (2012), Nguyen et al. (2014) etc.

Principal axis factoring is a confirmatory factor analysis method used in technology acceptance studies (Cheng et al., 2006) and its suitability is detected by Kaiser-MeyerOlkin (KMO) measure of sampling adequacy and Bartlett's test of sphericity. Bartlett's test of sphericity can confirm factorability, while it compares the observed correlation matrix to the identity matrix. It detects if there is a certain redundancy between the variables that can be summarized by a few number of factors. If the variables are perfectly correlated, only one factor is sufficient. The Kaiser-Meyer-Olkin (KMO) measure of sampling adequacy compares the values of correlations between variables and those of the partial correlations. If the $\mathrm{KMO}$ is close to one, the principal axis factoring can act efficiently; if it is KMO is close to zero, the principal axis factoring is not relevant (Kumar et al., 2012). As internal consistency reliability measure, the Cronbach's alpha was used, similarly as in Hair and Black (2010). Cronbach's alpha is the expected correlation of two tests that measure the same construct.

Factor analysis is frequently used as a first step to assess the proposed measurement model in a structural equation model (SEM). Many of the rules of interpretation regarding assessment of model fit and model modification in structural equation modeling apply equally to confirmatory factor analysis. While in confirmatory factor analysis factors are not presumed to directly cause one another, SEM often specifies particular factors and variables to be causal in nature (Hox \& Bechger, 1998). Therefore, the Structural Equation Modelling
(SEM) approach was further used to show relations between variables in our research model. Fundamentally, SEM is a term for a large set of techniques based on the general linear model and it has the ability to test relationships between constructs comprised from multiple items (Weinberg \& Abramovitz, 2002) and the capability of testing the measurement characteristics of constructs (Hair \& Black, 2010).

Hox and Bechger (1998) stated that a structural equation model implies a structure of the covariance matrix of the measures. Once the model's parameters have been estimated, the resulting model-implied covariance matrix can then be compared to an empirical or databased covariance matrix. If the two matrices are consistent with one another, then the structural equation model can be considered a plausible explanation for relations between the measures. The SEM approach offers greater ability to handle multicollinearity, inherent errors in measuring independent variables and estimation of parameters (Hair \& Black, 2010).

\section{Results}

The questionnaire survey was aimed to gather data to investigate factors influencing electronic banking adoption showed in our research model. The Likert seven-point scale was used for the answer options. Only individuals were addressed within our survey. Over 600 potential individual clients from Slovakia were asked to fill in the questionnaire. In total, 211 filled out surveys were gathered, what represents approximately 35 percent return rate of questionnaires. There were 104 questionnaires returned $(49.29 \%)$ from male respondents and 107 questionnaires $(50.71 \%)$ from female respondents in our conducted survey. This ratio corresponds well to the demographic composition of the population in Slovakia. Twothirds of respondents were younger than 40 years old. The biggest group of respondents (37.44\%) was younger than 25 years old. Above 29\% was between 25 and 40 years old and $24 \%$ between 41 and 55 years old. Over 55 years were only 19 respondents what represents $9 \%$ of respondents.

Following Tab. 1 contains all demographic characteristics of our survey respondents gathered.

Besides the demographic characteristics, Tab. 1 contains also electronic banking usage 


\section{Tab. 1: Demographic characteristics of survey respondents}

\begin{tabular}{|c|c|c|c|}
\hline Characteristic & Value & Frequency & Percentage \\
\hline \multirow[t]{2}{*}{ Sex } & Male & 104 & 49.29 \\
\hline & Female & 107 & 50.71 \\
\hline \multirow[t]{4}{*}{ Age } & Less than 25 years & 79 & 37.44 \\
\hline & Between 25 and 40 years & 62 & 29.38 \\
\hline & Between 41 and 55 years & 51 & 24.17 \\
\hline & Over 55 years & 19 & 9.00 \\
\hline \multirow[t]{4}{*}{ Electronic banking usage } & Does not use & 17 & 8.06 \\
\hline & Less than 1 year & 20 & 9.48 \\
\hline & Between 1 and 3 years & 80 & 37.91 \\
\hline & Over 3 years & 94 & 44.55 \\
\hline \multirow[t]{4}{*}{ Forms of e-banking used } & None & 17 & 8.06 \\
\hline & Internet banking & 124 & 58.77 \\
\hline & Smart banking & 1 & 0.47 \\
\hline & $\begin{array}{l}\text { Both Smart banking and } \\
\text { Internet banking }\end{array}$ & 69 & 32.70 \\
\hline \multirow[t]{5}{*}{ Frequency of usage per month } & None & 17 & 8.06 \\
\hline & 1-2 payments & 67 & 31.75 \\
\hline & 3-4 payments & 58 & 27.49 \\
\hline & 5-6 payments & 37 & 17.54 \\
\hline & More than 6 payments & 32 & 15.17 \\
\hline
\end{tabular}

of respondents detected in our survey. Since the survey was aimed at general population in Slovakia, there was a possibility for the respondent to indicate that he or she does not use any form of electronic banking. We recorded 17 responses of respondents not using any form of electronic banking what represents approximately 8 percent.

The remaining 194 survey respondents using electronic banking will be used for verification of our research model. Twenty of our respondents $(9.48 \%)$ have used electronic banking shorter than one year. Eighty respondents $(37.91 \%)$ stated between one and three years of electronic banking usage and ninety-four respondents $(44.55 \%)$ indicated over three years of usage.

Most of the respondents (124) were using internet banking what is over $58 \%$ of respondents. Only one user indicated using smart banking without using internet banking at the same time, while 69 users $(32.70 \%)$ stated that they use both smart banking and internet banking.

Further, the frequency of using electronic banking for payments was investigated. Over 31 percent of respondents (67) make 1 or 2 payments through electronic banking per month. Around 3 or 4 payments per month indicated 58 respondents what is 27.49 percent and 5 or 6 payments were stated by 37 respondents (17.54\%). Approximately 15 percent of respondents use electronic banking intensively, i.e. more than 6 payments during the month.

Each of our proposed factors is represented by group of multiple questions or statements, presented in Tab. 2.

Cumulative percentage of variance explained represents increasing portion of variance explained by an inclusion of all previous factors stated in table. For further analysis of data, IBM SPSS Statistics software was used. Potential factors of perceived security, trust, 


\begin{tabular}{|c|c|c|c|c|c|}
\hline Item & $\begin{array}{l}\text { Perceived } \\
\text { security }\end{array}$ & Trust & $\begin{array}{c}\text { Attitude } \\
\text { toward } \\
\text { using }\end{array}$ & $\begin{array}{c}\text { Behavioral } \\
\text { intention to } \\
\text { use } \\
\text { e-banking }\end{array}$ & $\begin{array}{c}\text { Actual } \\
\text { use of } \\
\text { e-banking }\end{array}$ \\
\hline $\begin{array}{l}\text { I have enough information about secure use } \\
\text { of electronic banking }\end{array}$ & .844 & & & & \\
\hline I use electronic banking securely & .782 & & & & \\
\hline $\begin{array}{l}\text { Transferring sensitive information via electronic } \\
\text { banking is secure }\end{array}$ & .903 & & & & \\
\hline Overall, using electronic banking is secure & .851 & & & & \\
\hline Electronic banking of my bank is trustworthy & & .887 & & & \\
\hline I trust in electronic banking of my bank & & .897 & & & \\
\hline Electronic banking keeps my best interests in mind & & .845 & & & \\
\hline Using electronic banking is a good idea & & & .863 & & \\
\hline Using electronic banking is convenient and pleasant & & & .900 & & \\
\hline $\begin{array}{l}\text { I consider electronic banking as suitable solution } \\
\text { of covering my needs of banking services }\end{array}$ & & & .834 & & \\
\hline $\begin{array}{l}\text { I intend to continue using electronic banking in the } \\
\text { future }\end{array}$ & & & & .867 & \\
\hline I will recommend others to use electronic banking & & & & .795 & \\
\hline I would always prefer e-banking & & & & .767 & \\
\hline $\begin{array}{l}\text { I am satisfied with advantages that electronic } \\
\text { banking usage brings }\end{array}$ & & & & .826 & \\
\hline I use electronic banking often & & & & & .849 \\
\hline $\begin{array}{l}\text { I use electronic banking more frequently than } \\
\text { classic banking }\end{array}$ & & & & & .822 \\
\hline $\begin{array}{l}\text { I use electronic banking as main way of using } \\
\text { banking services }\end{array}$ & & & & & .860 \\
\hline Percentage of variance explained & 31.838 & 17.704 & 17.441 & 12.979 & 6.630 \\
\hline Cumulative percentage of variance explained & 31.838 & 49.542 & 66.983 & 79.962 & 86.592 \\
\hline
\end{tabular}

attitude toward using and behavioral intention to use were investigated by confirmatory factor analysis. Specifically, principal axis factoring method with varimax rotation was used. This method is widely used in technology acceptance studies (e.g. Cheng et al. (2006), Yousafzai et al. (2009), Kumar et al. (2012) etc.). Foremost, Kaiser-Meyer-Olkin (KMO) measure of sampling adequacy and Bartlett's test of sphericity were expressed. Bartlett's test of sphericity confirmed factorability since it was significant at a value of 0.000 . Kaiser-MeyerOlkin (KMO) measure of sampling adequacy with value at 0.958 confirmed that factor analysis was appropriate because it surpassed required a minimum level of 0.60 for reliability (Kumar et al., 2012).

Cronbach's alpha serves as internal consistency reliability measure (Hair \& Black, 2010). Cronbach's alpha test was performed to test the reliability of constructs as standard test of reliability of constructs (Kumar et al., 2012). Tab. 3 contains Cronbach's alphas of all constructs considered in our model. Minimum level for reliability is Cronbach's alpha at the value of 0.70 (Suh \& Han, 2002; Hair \& Black, 2010). Our first factor identified was perceived security with four variables and Cronbach's 


\begin{tabular}{l|c}
\multicolumn{1}{c|}{ Construct } & Cronbach's Alpha \\
\hline Perceived security & 0.896 \\
\hline Trust & 0.921 \\
\hline Attitude toward using & 0.933 \\
\hline Behavioral intention to use & 0.914 \\
\hline Actual use & 0.859 \\
\hline
\end{tabular}

alpha at 0.896 . The factor of trust had three variables with Cronbach's alpha at 0.921 . The third factor of attitude towards using electronic banking mújcontained three variables and had Cronbach's alpha value at 0.933 . The fourth factor - behavioral intention to use electronic banking consisted of four variables with Cronbach's alpha of 0.914 . The last factor is actual use of electronic banking and Cronbach's alpha at the level of 0.859 .

The identified factors in Tab. 2 had eigenvalue above 1 and explained 86.59 percent of variable's variance in total.

We further used a Structural Equation Modelling (SEM) approach to validate the research model. This method was chosen for its ability to test relationships between constructs comprised from multiple items (research questions) (Weinberg \& Abramovitz, 2002) and the capability of testing the measurement characteristics of constructs (Hair \& Black, 2010). The SEM approach offers several advantages over the conventional regression approach by providing greater facility in handling multicollinearity, inherent errors in measuring independent variables and estimation of parameters (Hair \& Black, 2010). Also this method is widely used in studies on similar topic (e.g. Suh \& Han (2002), Yousafzai et al. (2009), Nguyen et al. (2014)). AMOS extension of IBM SPSS Statistics software was used to perform further analysis. We used correlation matrix as input matrix to simplify interpretation of results. In the SEM approach, the validity of factors can be assessed by multiple fit indices. Tab. 4 shows overall fit indices of our research model.

All overall model fit indices surpassed the recommended values, therefore our research model has good representation of relationships between factors.

\section{Tab. 4: Overall model fit indices of our model}

\begin{tabular}{l|r|c} 
& Score & Recommended value \\
\hline Chi-square & 43.015 & \\
\hline Degree of freedom & 17 & \\
\hline Chi-square/degree of freedom & 2.532 & $<3.00$ \\
\hline Goodness-of-fit index (GFI) & 0.827 & $>0.80$ \\
\hline Adjusted goodness-of-fit index (AGFI) & 0.894 & $>0.80$ \\
\hline Root mean square residual (RMSR) & 0.071 & $<0.08$ \\
\hline Normed fit index (NFI) & 0.924 & $>0.90$ \\
\hline Non-normed fit index (NNFI) & 0.922 & $>0.90$ \\
\hline Comparative fit index (CFI) & 0.951 & $>0.90$ \\
\hline
\end{tabular}




\section{Tab. 5: Overall model fit indices of our model}

\begin{tabular}{l|c|c}
\multicolumn{1}{c|}{ Construct } & Composite reliability & Variance extracted \\
\hline Recommended value & $>0.8$ & $>0.5$ \\
\hline Perceived security & 0.864 & 0.680 \\
\hline Trust & 0.937 & 0.861 \\
\hline Attitude toward using & 0.901 & 0.769 \\
\hline Behavioral intention to use & 0.879 & 0.793 \\
\hline Actual use & 0.826 & 0.597 \\
\hline
\end{tabular}

Source: own

Note: recommended values from Suh and Han (2002).

The validity of measurement can be assessed by composite reliability and the variance extracted measure. Composite reliability depicts the degree to which the items indicate the common construct. The variance extracted measure reflects the amount of variance in the items captured by the construct. Composite reliability and variance extracted by our research model constructs are presented at Tab. 5.

All composite reliabilities were above recommended value of 0.8 and all variance extracted measures were above recommended level of 0.5 . This results demonstrate overall validity of constructs or factors used. Further we examined the estimated coefficients of the relationships between constructs, which would validate the hypotheses from our research model.

Firstly, hypothesis $\mathrm{H} 1$ examined the impact of perceived security on trust was investigated. It was observed that perceived security had a significant impact on trust in electronic banking $(\beta=0.793, t=11.224, P<0.01)$. The model explained $72.4 \%$ of the variance in trust $\left(R^{2}=0.724\right)$. Our results support hypothesis $\mathrm{H} 1$, so perceived security has a significant positive impact on customer's trust in electronic banking.

Further, the relationship between perceived security and customer's attitude toward using electronic banking was expressed. Statistically significant $(\beta=0.453, t=8.957, P<0.01)$ influence of security perceived by the customer on attitude toward using was detected. The results support hypothesis $\mathrm{H} 2$ stating that perceived security has a significant positive impact on customer's attitude toward using electronic banking. Also, the influence of trust on attitude toward using was examined and found to be statistically significant $(\beta=0.357$, $t=5.742, P<0.01)$. This result supported hypothesis $\mathrm{H} 3$ and thus customer's trust has significant positive impact on customer's attitude toward using electronic banking. These two factors explained $59.2 \%$ of the variance $\left(R^{2}=0.592\right)$ in attitude toward using electronic banking.

Further, the investigation of the impact of trust and attitude toward using electronic banking on customer's behavioral intention was conducted. The influence of trust on behavioral intention to use electronic banking was detected as significant $(\beta=0.471, t=7.867, P<0.01)$. The impact of attitude toward using on behavioral intention to use electronic banking was also significant $(\beta=0.385, t=6.027, P<0.01)$. These results support our hypotheses $\mathrm{H} 4$ and $\mathrm{H} 5$ and hence trust and attitude toward using electronic banking have significant positive influence on customer's behavioral intention to use electronic banking. These factors explained $63.7 \%$ of variance $\left(R^{2}=0.637\right)$ in customer's behavioral intention. Finally, the influence of customer's behavioral intention to use banking on its actual use was examined and it was found significant $(\beta=0.359, t=4.911, P<0.01)$. The results support hypothesis $\mathrm{H} 6$ and customer's behavioral intention to use electronic banking has a significant positive impact on customer's actual use of electronic banking explaining $21 \%$ of variance $\left(R^{2}=0.209\right)$. Overview of impacts detected by model are summarized in following Tab. 6.

Our research model with relationships and values of coefficients displayed is presented 
Tab. 6: Influence between constructs detected by model

\begin{tabular}{l|l|c|c|c} 
Dependent construct & \multicolumn{1}{|c|}{$\begin{array}{c}\text { Independent } \\
\text { construct }\end{array}$} & $\boldsymbol{\beta}$ & $\boldsymbol{t}$ & $\boldsymbol{P}$ \\
\hline Trust & Perceived security & $0.793^{*}$ & 11.224 & 0.000 \\
\hline Attitude toward using & Perceived security & $0.453^{*}$ & 8.957 & 0.001 \\
\hline Attitude toward using & Trust & $0.357^{*}$ & 5.742 & 0.002 \\
\hline $\begin{array}{l}\text { Behavioral intention } \\
\text { to use }\end{array}$ & Trust & $0.471^{*}$ & 7.867 & 0.001 \\
\hline $\begin{array}{l}\text { Behavioral intention } \\
\text { to use }\end{array}$ & Attitude toward using & $0.385^{*}$ & 6.027 & 0.001 \\
\hline Actual use & $\begin{array}{l}\text { Behavioral intention } \\
\text { to use }\end{array}$ & $0.359^{*}$ & 4.911 & 0.003 \\
\hline
\end{tabular}

Source: own

Note: *Significant at $\alpha=0.01 ; \beta-$ measures the prediction of the dependent construct from independent i.e. represents relation between constructs, $t$-value measures the size of the difference relative to the variation in sample data i.e. shows whether a coefficient is significantly different from zero., P-value tests the null hypothesis that the coefficient is equal to zero i.e. probability that construct has no effect.

\section{Fig. 2: Structural model fit}

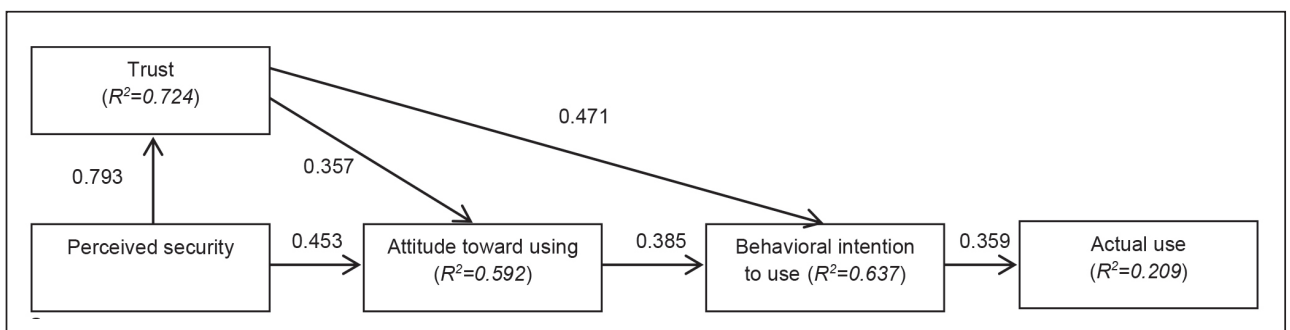

Source: own

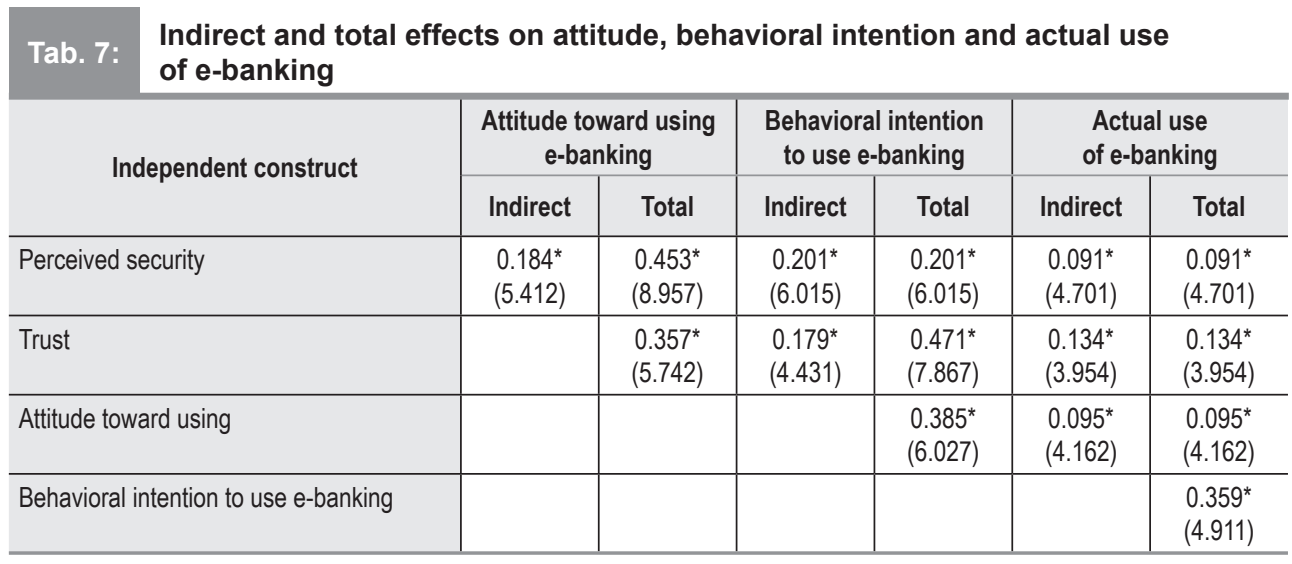

Note: *significant at $\alpha=0.05$. t-values are in parentheses 
in the Fig. 2. The coefficients represent measure of detected influences between suggested factors from confirmatory factor analysis. The coefficients of determination $\left(R^{2}\right)$ for each endogenous construct are also shown in the figure.

Suh and Han (2002) in their study expressed indirect effect of trust on attitude toward using, behavioral intention to use and actual use of electronic banking. In our research, besides trust also perceived security and its effects on attitude toward using, behavioral intention to use and actual use were investigated. Our results show that both perceived security and trust have a significant effect on attitude toward using and behavioral intention to use which has direct effect on actual use and hence trust and perceived security have an indirect effect also on adoption of electronic banking. So additional step of SEM approach analysis was performed to identify indirect effects and total effects on attitude, behavioral intention and actual use of e-banking. Its results are illustrated in Tab. 7 .

All factors had significant effects on attitude toward using, behavioral intention to use and actual use of electronic banking at $\alpha=0.05$.

\section{Conclusions}

In this study, we proposed research model based on adjusted TAM indicating a relationship between perceived security, trust, attitude toward using electronic banking and behavioral intention to use electronic banking. Perceived security was found a very important factor of trust building in the area of electronic banking and significant factor influencing attitude toward using it.

Trust was detected to have a significant influence on attitude toward using and behavioral intention to use electronic banking by customers. Further attitude toward using e-banking had a significant effect on behavioral intention to use electronic banking and subsequently the actual use of electronic banking by bank customers was significantly influenced by behavioral intention to use electronic banking by bank customers. These results correspond with results of multiple studies, e.g. Polatoglu and Ekin (2001), Black et al. (2002), Grabner-Kräuter and Faullant (2008) or Nguyen et al. (2014).

Security and trust have a significant effect on attitude toward using and behavioral intention to use according to our results and therefore influence the process of adoption of electronic banking by customers. Suh and Han (2002) already showed that trust indirectly influences acceptance of electronic banking. Our research confirmed the influence of trust on electronic banking adoption. In addition, our study also included perceived security into research model and confirmed its influence on electronic banking adoption by potential users.

Our results suggest to the bank managers at Slovak retail banking market to build trust in electronic banking by increasing its security perceived by potential users. Banks should communicate every positive change in security standards of their electronic banking forms to improve confidence of clients when using it. This will promote adoption of electronic banking according to our results. Increased actual use of electronic banking might help to decrease labor consumption at brick-and-mortar branches of banks, while multiple time-consuming services (e.g. typing of bank transfers, creating account statements etc.) are advanced to clients themselves in electronic banking.

Furthermore, the novelty of our research is also in applying research of security and trust influencing electronic banking adoption in Slovakia, contributing to knowledge of conditions at Slovak retail banking market and customers. Our model might be used also in other fields of e-services (like e-commerce) adoption in both, Slovak and international conditions.

Our results are significant, but still have limitations of validity. The ideal representativeness of our sample was not achieved, affecting the generalization of results. A number of respondents in our sample (194) was also relatively lower than in multiple other studies (e.g. Nguyen et al. (2014), Suh and Han (2002) etc.) restricting the validity of our results.

Many studies using Technology Acceptance Model modified original TAM to investigate various factors affecting acceptance of given technology creating new versions of TAM. Also, our model can be further modified and extended by new factors to investigate their effects. Furthermore, our future research might be conducted in the sector of small and medium-sized enterprises.

\section{References}

Agarwal, R., \& Karahanna, E. (2000). Time flies when you're having fun: cognitive 
absorption and beliefs about information technology usage. MIS Quarterly, 24(4), 665694. doi:10.2307/3250951.

Aladwani, A. M. (2001). Online banking: a field study of drivers, development challenges, and expectations. International Journal of Information Management, 21(2), 213-225. doi:10.1016/S0268-4012(01)00011-1.

Alsajjan, B. A., \& Dennis, C. (2006). The Impact of Trust on Acceptance of Online Banking. European Association of Education and Research in Commercial Distribution. West London: Brunel University.

Alsajjan, B., \& Dennis, C. (2010). Internet banking acceptance model: Cross-market examination. Journal of Business Research, Advances in Internet Consumer Behavior \& Marketing Strategy, 63(9-10), 957-963. doi:10.1016/j.jbusres.2008.12.014.

Berger, S. C., \& Gensler, S. (2007). Online banking customers: Insights from Germany. Journal of Internet Banking and Commerce, 12(1), 1-6.

Bhattacherjee, A. (2002). Individual trust in online firms: Scale development and initial test. Journal of Management Information Systems, 19(1), 211-241. doi:10.1080/07421222.2002.1 1045715.

Black, N. J., Lockett, A., Winklhofer, H., \& McKechnie, S. (2002). Modelling consumer choice of distribution channels: an illustration from financial services. International Journal of Bank Marketing, 20(4), 161-173. doi:10.1108/02652320210432945.

Chellappa, R. K., \& Pavlou, P. A. (2002). Perceived information security, financial liability and consumer trust in electronic commerce transactions. Logistics Information Management, 15(5/6), 358-368. doi:10.1108/09576050210447046.

Cheng, E. T. C., Lam, D. Y. C., \& Yeung, A. C. L. (2006). Adoption of internet banking: An empirical study in Hong Kong. Decision Support Systems, 42(3), 1558-1572. doi:10.1016/j. dss.2006.01.002.

Claessens, S., Glaessner, T., \& Klingebiel, D. (2002). Electronic Finance: Reshaping the Financial Landscape around the World. Journal of Financial Services Research, 22(1), 29-61. doi:10.2139/ssrn.271935.

Dandapani, K. (2004). Success and Failure in Web-based Financial Services. Communications of the ACM, 47(5), 31-33. doi:10.1145/986213.986233.
Davis, F. D. (1989). Perceived usefulness, perceived ease of use, and user acceptance of information technology. MIS Quarterly, 13(3), 319-336. doi:10.2307/249008.

Davis, F. D., Bagozzi, R. P., \& Warshaw, P. R. (1989). User acceptance of computer technology: a comparison of two theoretical models. Management Science, 35(8), 982-1003. doi:10.1287/mnsc.35.8.982.

Delina, R., \& Dráb, R. (2010). Socioeconomic aspects of trust building for the electronic business platforms. E\&M Ekonomie a Management, 13(4), 110-122.

Dzemydienè, D., Naujikienè, R., Kalinauskas, M., \& Jasiūnas, E. (2010). Evaluation of Security Disturbance Risks in Electronic Financial Payment Systems. Intellectual Economics, 2(8), 21-29.

Gefen, D. (2002). Reflections on the dimensions of trust and trustworthiness among online consumers. ACM SIGMIS Database for Advances in Information Systems, 33(3), 38-53. doi:10.1145/569905.569910.

Gefen, D., Karahanna, E., \& Straub, D. W. (2003). Inexperience and experience with online stores: The importance of TAM and trust. IEEE Transactions on Engineering Management, 50(3), 307-321. doi:10.1109/ TEM.2003.817277.

George, F. F. (2002). Influences on the intent to make Internet purchases. Internet Research: Electronic Networking Applications and Policy, 12(2), 165-180. doi:10.1108/10662240210422521.

Geetha, K. T., \& Malarvizhi, V. (2011). Acceptance of E-Banking among Customers (An Empirical Investigation in India). Journal of Management and Science, 2(1), 1-9.

Grabner-Kräuter, S., \& Faullant, R. (2008). Consumer acceptance of internet banking: the influence of internet trust. International Journal of Bank Marketing, 26(7), 483-504. doi:10.1108/02652320810913855.

Hair, J. F., \& Black, W. C. (2010). Multivariate Data Analysis. Upper Saddle River, N.J.: Pearson Prentice-Hall.

Hamlet, C., \& Strube, M. (2000). Community banks go online. ABA Banking Journal's 2000 White Paper/Banking on the Internet, March, 61-65.

Hawkins, J., \& Sato, S. (2004). Electronic Finance: an overview of the issues. Communications of the ACM, 49(7), ACM.org, BIS workshop, Basel. 
Howcroft, B., Hamilton, R., \& Hewer, P. (2002). Consumer attitude and the usage and adoption of home-based banking in the United Kingdom. The International Journal of Bank Marketing, 20(3), 111-121. doi:10.1108/02652320210424205.

Hox, J., \& Bechger, T. (1998). An Introduction to Structural Equation Modelling. Family Science Review, 11(1998), 354-373.

Jarvenpaa, S. L., Tractinsky, N., \& Vitale, M. (2000). Consumer trust in an Internet store. Information Technology and Management, 1, 45-71.

Jöreskog, K. G. (1969). A general approach to confirmatory maximum likelihood factor analysis. Psychometrika, 34(2), 183-202.

Karjaluoto, H., Mattila, M., \& Pento, T. (2002). Factors underlying attitude formation toward online banking in Finland. International Journal of Bank Marketing, 20(6), 261-272. doi:10.1108/02652320210446724.

Kumar, M., Sareen, M., \& Barquissau, E. (2012). Relationship between types of trust and level of adoption of Internet banking. Problems and Perspectives in Management, 10(1), 82-92.

Lee, M. K. O., \& Turban, E. (2001). A Trust Model for Consumer Internet Shopping. International Journal of Electronic Commerce, 6(1), 75-91.

Lev-On, A. (2009). Cooperation with and without Trust Online. In e-Trust Forming Relationships in the Online World (pp. 292318). New York: Russell Sage Foundation.

Liao, Z., \& Cheung, M. T. (2002). Internetbased e-banking and consumer attitudes: an empirical study. Information \& Management, 39(4), 283-295. doi:10.1016/S0378-7206(01)00097-0.

Macintosh, G., \& Lockshin, L. S. (1997). Retail relationships and store loyalty: a multilevel perspective. International Journal of Research in Marketing, 14(5), 487-497. doi:10.1016/S0167-8116(97)00030-X.

McKnight, D. H., Choudhury, V., \& Kacmer, C. (2002). The impact of initial trust on intentions to transact with a web site: a trust building model. Journal of Strategic Information Systems, 11(3-4), 297-323. doi:10.1016/S09638687(02)00020-3.

Mittal, R. K., \& Kumra, R. (2004). Trust and its Determinants in Internet Banking: A Study of Private Sector Banks in India. Decision, 31(1), 73-96.

Moga, L. M., Nor, K. M., Neculita, M., \& Khani, N. (2012). Trust and Security in E-banking
Adoption in Romania. Communications of the IBIMA, 2012, 1-10. doi:10.5171/2012.583012.

Moon, J., \& Kim, Y. (2001). Extending the TAM for a World-Wide-Web context. Information and Management, 38(4), 217-230. doi:10.1016/ S0378-7206(00)00061-6.

Nguyen, L., Nguyen, D. T., \& Singh, T. (2014). Effect of Trust on Customer Intention to use Electronic Banking in Vietnam. In Proceedings of Global Business and Finance Research Conference 2014 (pp. 1-24). Melbourne: Marriott Hotel.

Pavlou, P. A. (2003). Consumer Acceptance of Electronic Commerce: Integrating Trust and Risk with the Technology Acceptance Model. International Journal of Electronic Commerce, 7(3), 69-103.

Pikkarainen, T., Pikkarainen, K., Karjaluoto, H., \& Pahnila, S. (2004). Consumer acceptance of online banking: an extension of the technology acceptance model. Internet Research, 14(3), 224-235. doi:10.1108/10662240410542652.

Polatoglu, V. N., \& Ekin, S. (2001). An empirical investigation of the Turkish consumers' acceptance of Internet banking services. International Journal of Bank Marketing, 19(4), 156-165. doi:10.1108/02652320110392527.

Popoola, N. F. (2013). The Effect of Trust in Adoption of Internet Banking: A case study of Nigeria. International Journal of Economic and Business Management, 1(2), 19-24.

Qureshi, T. M., Zafar, M. K., \& Khan, M. B. (2008). Customer Acceptance of Online Banking in Developing Economies. Journal of Internet Banking and Commerce, 13(1), 1-9.

Roboff, G., \& Charles, C. (1998). Privacy of financial information in cyberspace: banks addressing what consumers want. Journal of Retail Banking Services, 20(3), 51-56.

Sanayei, A., \& Noroozi, A. (2009). Security of Internet Banking Services and its Linkage with Users' Trust: A Case Study of Parsian Bank of Iran and CIMB Bank of Malaysia. In Proceeding ICIME '09 Proceedings of the 2009 International Conference on Information Management and Engineering, (pp. 3-7). IEEE Computer Society Washington, DC. doi:10.1109/ICIME.2009.153.

Sathye, M. (1999). Adoption of Internet banking byAustralian consumers: an empirical investigation. International Journal of Bank Marketing, 17(7), 324-334. doi:10.1108/02652329910305689.

Simpson, J. (2002). The impact of the Internet in banking: observations and from developed and emerging markets. Telematics 
and Informatics, 19, 315-330. doi:10.1016/ S0736-5853(01)00019-3.

Sohail, S., \& Shanmugham, B. (2003). E-banking and customer preferences in Malaysia: An empirical investigation. Information Sciences, 150, 207-217.

Šoltés, V., \& Gavurová, B. (2014). The Functionality Comparison of the Health Care Systems by the Analytical Hierarchy Process Method. E\&M Ekonomie a Management, 17(3), 100-117. doi:10.15240/tul/001/2014-3-009.

Suh, B., \& Han, I. (2002). Effect of trust on customer acceptance of Internet banking. Electronic Commerce Research and Applications, 1(3-4), 247-263. doi:10.1016/ S1567-4223(02)00017-0.

Tan, Y., \& Thoen, W. (2001). Toward a generic model of trust for electronic commerce. International Journal of Electronic Commerce, 5(2), 61-74. doi:10.1080/1086441 5.2000 .11044201

Teo, T. S. H., Lim, V. K. G., \& Lai, R. Y. C. (1999). Intrinsic and extrinsic motivation in Internet usage. Omega International Journal of Management Science, 27(1), 25-37. doi:10.1016/S0305-0483(98)00028-0.

Vejačka, M. (2014). Customer acceptance of electronic banking: Evidence from Slovakia. Journal of Applied Economic Sciences, 9(3), 514-522.

Venkatesh, V., \& Davis, F. D. (2000). Theoretical extension of the technology acceptance model: four longitudinal field studies. Management Science, 46(2), 186-204. doi:10.1287/mnsc.46.2.186.11926.
Voříšek, J., Pour, J., \& Buchalcevová, A. (2015). Management of Business Informatics Model - Principles and Practices. E\&M Ekonomie a Management, 18(3), 160-174. doi:10.15240/tul/001/2015-3-014.

Weinberg, S. L., \& Abramovitz, S. K. (2002). Data analysis for the behavioral sciences using SPSS. Cambridge University Press.

Werber, B., Rajkovič, U., Urh, M., \& Žnidaršič, A. (2015). Computer Literacy and Use of ICT as Key Factors of Micro-Enterprise Success. E\&M Ekonomie a Management, 18(2), 165-182. doi:10.15240/tul/001/2015-2-012.

Widjana, M. A., \& Rachmat, B. (2011). Factors Determining Acceptance Level of Internet Banking Implementation. Journal of Economics, Business and Accountancy, 14(2), 161-174. doi:10.14414/jebav.v14i2.5.

Yousafzai, S., Pallister, J. G., \& Foxall, G. R. (2009). Multidimensional role of trust in Internet banking adoption. The Service Industries Journal, 29(5), 591-605. doi:10.1080/02642060902719958.

Ing. Martin Vejačka, PhD. Technical University of Košice Faculty of Economics Department of Applied Mathematics and Business Informatics martin.vejacka@tuke.sk

Ing. Tomáš Štofa Technical University of Košice Faculty of Economics Department of Banking and Investment tomas.stofa@tuke.sk 


\section{Abstract}

\section{INFLUENCE OF SECURITY ANDTRUST ON ELECTRONIC BANKING ADOPTION IN SLOVAKIA}

\section{Martin Vejačka, Tomáš Štofa}

Dynamical development of information and communication technologies has been one of the major factors of economic growth in recent decades. Electronic commerce allowed selling and buying of products or services to many times larger number of customers than ever before. Electronic banking as a part of electronic commerce is nowadays very important distribution channel for banking services. With the intense development of information and communication technologies also several forms of electronic banking arose and also vanished. Especially mobile banking recorded turbulent development in recent decades. Mobile banking in smart devices together with internet banking are now the main forms asserting in the electronic banking market. Competition among banks in the field of electronic banking pushes them to improve their electronic banking services to sustain or increase their market share. The important issue is trust of bank customers in the form of electronic banking used. Banks' customers also sensitively perceive security of electronic banking forms used by them.

In this article, we mainly investigated the influence of security and trust on electronic banking adoption. Research model based on technology acceptance model was developed and research hypotheses based on this research model were constructed. Data for hypotheses verification was gathered by online survey with 211 answering respondents. The influence of perceived security, trust, attitude toward using and behavioral intention to use electronic banking in Slovakia was examined using factor analysis. The results reveal that all factors investigated have statistically significant direct and indirect effects on electronic banking adoption by users on the Slovak retail banking market.

Key Words: Trust, security, technology acceptance model, electronic banking, internet banking, mobile banking.

JEL Classification: G29, L86.

DOI: 10.15240/tul/001/2017-4-010 